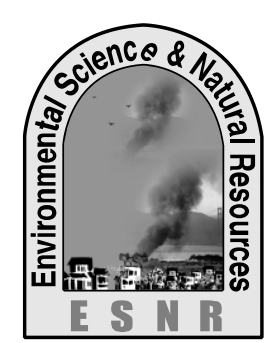

\title{
Effect of Temperature on Flower and Pod Abscission and Yield of Three Soybean Genotypes
}

\author{
A. B. M. A. Hoque ${ }^{1 *}$, M. M. Hassan ${ }^{1}$, M. M. K. Khan ${ }^{2}$, R. Khatun ${ }^{1}$ and M. A. Baten ${ }^{1}$
}

${ }^{1}$ Department of Environmental Science, Bangladesh Agricultural University, Mymensingh

${ }^{2}$ Soil Science Division, Bangladesh Institute of Nuclear Agriculture (BINA), Mymensingh

Corresponding author: hoqueabm@gmail.com

\section{Abstract}

A pot experiment was conducted at Soil Science Division, Bangladesh Institute of Nuclear Agriculture (BINA), Mymensingh, during January to April 2014 to investigate the growth, abscission of flower and pod and yield performance of three soybean varieties (BINA Soybean-1, BINA Soybean-2, and Shohag) under three different temperature conditions. Flower abscission number and percentage were maximum in elevated temperature but the abscission of pods plant ${ }^{-1}$ was found to be the maximum in ambient temperature. In case of the performance of varieties, tallest plant and maximum node plant $^{-1}$ were noted from the variety Shohag but number of nodules plant ${ }^{-1}$, number of seeds pod ${ }^{-1}$, weight of 100 seed and seed yield was highest in BINA soybean-2 while BINA soybean-1 had maximum flowers plant $^{-1}$ and pods plant ${ }^{-1}$. Abscission of flowers plant ${ }^{-1}$ was maximum in BINA soybean-1 under elevated temperature while similar variety grown under ambient temperature obtained the maximum abscission of pods plant $^{-1}$ and the variety Shohag grown under elevated temperature noted the maximum abscission percentage of flower at all the data recording stages. These results suggested that ambient temperature and BINA soybean-2 singly or their interaction would be the most significant compared to others.

Key words: Morpho-physiological attributes, Temperature effect, Varietal effect, Yield attributes

\section{Introduction}

Soybean (Glycine max (L.) Merr) is one of the most important grain legume of the world and a new prospective crop for Bangladesh. Cultivation of soybean covered about 55,000 hectares of land and produced about 90,000 metric tons of seeds during the period of 2009-2010 in Bangladesh (Anonymous, 2011). Soybean is very sensitive to variation in photoperiod, temperature and water availability. The suitable temperature for soybean is $15-22^{\circ} \mathrm{C}$ at emergence, $20-25^{\circ} \mathrm{C}$ at flowering, and $15-22^{\circ} \mathrm{C}$ at maturity (Liu et al., 2008). Soybean seed yield increased as the day/night temperature increased between $18 / 12^{\circ} \mathrm{C}$ and $26 / 20^{\circ} \mathrm{C}$, but yield decreased when plants were grown at temperature greater than 26/20 ${ }^{\circ} \mathrm{C}$ (Huxley et al., 1976). Raising temperature from $29^{\circ} \mathrm{C}$ to $34^{\circ} \mathrm{C}$ during seed fill decreased soybean seed yield (Dornobos and Mullen, 1991).Temperature above $40^{\circ} \mathrm{C}$ causes severe pod abortion in soybean (Mann and Jaworski, 1970). High temperature accelerate the abscission process of developing the reproductive organs and affect in pod set and yield in soybean (Saito et al., 1970; Ashley and Ethridge, 1978; Korte et al., 1983). Flower set and retention in legumes is affected by high day-temperature and low available soil moisture (Davis, 1945; Stobbe et al., 1966; Fisher and Weaver, 1974). Hot weather imposing temporary heat and /or drought stresses during reproductive development enhanced flower and pod abscission (Konsens, 1991). High temperature also enhanced the maturing of crop (Suppiah, 1997). Global temperature would increase $4^{\circ} \mathrm{C}$ by $2100 \mathrm{AD}$ and it would probably decrease the production of most crops by about $25 \%$ (Lawlor, 1997). Jiwu and Hong (1997) also reported that ascending air temperature would influence soybean production in future. Photosynthesis and seed characteristics are the primary determinants of pod and seed number (Eglib, 2005), but recent research suggests that the temporal distribution of flower production may also play an important role. The present study was conducted to assess the effect of temperature on flower and pod abscission of soybean and their yield at the three temperature conditions (ambient, high, and cool).

\section{Materials and Methods}

The pot experiment was conducted in a controlled plant growth chamber and open field at the field laboratory of the Department of Soil Science, Bangladesh Institute of Nuclear Agriculture (BINA) during the period from January to May 2014. The experimental area was under the subtropical climate, which was characterized by moderately low temperature during Rabi season (October to March) and scanty rainfall associate with high temperature, high humidity and heavy precipitation with occasional gusty winds in Kharif-1 season (April to July) under Old Brahmaputra Flood Plain Agro-Ecological Zone. The soil was silty loam in texture having $\mathrm{pH}$ 6.7. Three soybean genotypes viz., BINA soybean-1, BINA soybean-2, Shohag (PB-1) were used as planting materials. Thirty six pots were prepared and their individual weight was recorded. Three seeds were sown by hand at a depth of $0.01 \mathrm{~m}$ on 15 January 2014 in each pot with the aim of growing one plant up to maturity. After germination, one healthy seedling was kept in each pot at 20 DAS. The experiment was laid out in CRD with three temperature treatments as ambient, elevated and cool condition with four replication. Out of 36 pots, the 12 pots were placed in elevated condition and another 12 pots were in cool condition. The rest 12 pots were placed in ambient condition. Irrigation was done two times a day at morning $(8.00 \mathrm{am})$ and afternoon $(5.00 \mathrm{pm})$. Air temperature was recorded in a clear sunny day with Psychrometer (Testo 615, GM 295-14770, German) at one hour interval from 10 am to $4 \mathrm{pm}$ on the month of March, 2014. Plant height, node number plant ${ }^{-1}$, nodule number plant ${ }^{-1}$, flower number plant ${ }^{-1}$, pod number plant $^{-1}$, seed number plant ${ }^{-1}$, seed weight plant ${ }^{-1}$ were recorded after final harvest. The data were analyzed 
statistically and the means were adjusted by DMRT at $5 \%$ level of significance.

\section{Results and Discussion}

Interaction effect between various types of temperature and varieties on morpho-physiological, yield attributing characters and yield of soybean

The interaction effect of various temperatures and varieties on plant height, nodes plant ${ }^{-1}$, nodules plant ${ }^{-1}$, flowers plant ${ }^{-1}$, pods plant ${ }^{-1}$, seeds pod ${ }^{-1}$, weight of 100 seed and seed yield are shown in Table 1. In Table 1, subscript $\mathrm{a}, \mathrm{b}$ and $\mathrm{c}$ means values within a column followed by the same letter are not significantly different, LSD means least significant difference, LS means level of significance (1\%) and NS means nonsignificant. The observed characteristics of plant in different temperature conditions are mentioned below.

\section{Plant height}

Interaction effect of various types of temperature and soybean varieties on plant height showed significant difference (varied from 0.405 to $0.622 \mathrm{~m}$ ) (Table 1).The significant tallest plant was found in variety Shohag grown under elevated temperature treatment followed by the similar variety grown under ambient temperature condition $(0.522 \mathrm{~m})$.On the other hand, the shortest plant was obtained from the variety BINA Soybean-2 at elevated temperature condition $(0.405 \mathrm{~m})$. Wang (2001) found that high temperature increased the plant height as well as the length of the nodes due to the increase of phenolic acid, flavonols, and antho-cyanins contents in plants.

\section{Number of nodes plant ${ }^{-1}$}

The node development was faster in elevated temperature and significantly higher number of nodes per plant (9.06) was found in the variety Shohag (Table $1)$. The lowest number of nodes per plant was found in BINA soybean-2 (6.40) in cool temperature while statistically similar lower number of nodes per plant was also obtained by the rest of the soybean varieties in similar (cool condition) treatment (Table 1).

\section{Number of nodules plant ${ }^{-1}$}

The maximum number of nodules per plant (96.40) was found in BINA Soybean-2 at ambient temperature (Table 1). On the other hand, opposite result was prevailed in cool condition at Shohag variety (33.80) (Table 1). Margesin and Schinner (1999) also reported that extreme lower temperature can drastically reduce the number of nodule in soybean plant.

\section{Number of flowers plant ${ }^{-1}$}

The maximum number of flowers per plant (115.10) was found from the variety BINA Soybean-1 grown under elevated temperature treatment which was statistically differed from other interaction treatments (Table 1). On the other hand, the variety Shohag grown under cool temperature treatment showed significantly the minimum number of flowers per plant (85.30) which was also statistically differed from other interactions (Table 1). All three varieties of the present study showed reduced number of flowers per plant under cool temperature treatment than ambient and elevated temperature treatment. This finding was fully agreed to the findings of Fakir et al. (2000).

\section{Number of pods plant ${ }^{-1}$}

The effect of varieties and temperature treatment on pod number per plant was significant (Table 1). At maturity, the highest pod number per plant was found (59.75) in BINA Soybean-1 under ambient temperature, on the contrary, the lower number of pod were shown in variety Shohag at elevated temperature, however, statistically similar pod per plant of BINA Soybean-2 was in ambient and cool temperature treatment. Ofier et al. (1993) reported that pod number of phaseolus vulgaris was significantly reduced by exposure to a high temperature of $32 / 27^{\circ} \mathrm{C}$ (day/night) for 5 days at anthesis, compared to $22 / 17^{\circ} \mathrm{C}$. The reduction was caused by an increased abscission to flower buds, flowers and young pod and by the failure of fertilization and seed development.

Number of seeds pod $^{-1}$

Number of seed per pod was statistically identical among the whole interaction between temperature treatments and soybean varieties (Table 1).

\section{Weight of 100 seed}

Interaction effect of soybean varieties and various types of temperature treatments showed significant variation in respect of 100 seed weight (Table 1). The highest weight was found (13.20) in BINA Soybean-2 under ambient temperature, On the contrary, the lower number of pod were shown in variety Shohag at cool temperature, However, BINA Soybean-1 gave statistically similar pod per plant in ambient and elevated temperature treatment.

\section{Seed yield}

From the Table 1, it was evident that the highest seed yield (19.16 gm plant ${ }^{-1}$ ) was found in BINA Soybean-2 under ambient temperature followed by the variety BINA soybean-1 under similar temperature treatments $(18.55$ gm plant $^{-1}$ ). Likewise, the lowest seed yield (8.61 gm plant $^{-1}$ ) was obtained from the variety Shohag grown under elevated temperature followed by the similar variety grown under cool temperature (9.47 gm plant $^{-1}$ ). The result indicated that the elevated and cool temperature decreased the seed yield regarding all varieties. Similar results were found by Terashima (2001), Shi et al. (2001), Morita. (2000), Robins and Domingo (1953). Imposing any kind of high temperature is expected to increase the process of abscission and thereby reduce the yield of soybean. Plant response to high temperature was most severe during the periods of rapid growth and development. 
Table 1. Interaction effect between various types of temperature and varieties on morpho-physiological parameters, yield attributing characters and yield of soybean

\begin{tabular}{|l|l|l|l|l|l|l|l|l|}
\hline Varieties & $\begin{array}{l}\text { Plant } \\
\text { height }(\mathbf{m})\end{array}$ & $\begin{array}{l}\text { No. of } \\
\text { nodes } \\
\text { plant }^{-1}\end{array}$ & $\begin{array}{l}\text { No. of } \\
\text { nodules } \\
\text { plant }^{-1}\end{array}$ & $\begin{array}{l}\text { No. of } \\
\text { flowers } \\
\text { plant }^{-1}\end{array}$ & $\begin{array}{l}\text { No. of } \\
\text { pods } \\
\text { plant }^{-1}\end{array}$ & $\begin{array}{l}\text { No. of } \\
\text { seeds } \\
\text { pod }^{-1}\end{array}$ & $\begin{array}{l}\text { 100 seed } \\
\text { weight }^{(\mathbf{g})}\end{array}$ & $\begin{array}{l}\text { Yield } \\
\text { (gm } \\
\left.\text { plant }^{-1}\right)\end{array}$ \\
\hline $\begin{array}{l}\text { Ambient x BINA } \\
\text { Soyaben-1 }\end{array}$ & $0.484 \mathrm{c}$ & $6.80 \mathrm{~cd}$ & $88.60 \mathrm{~b}$ & $110.60 \mathrm{~b}$ & $59.75 \mathrm{a}$ & 2.43 & $12.80 \mathrm{c}$ & $18.55 \mathrm{~b}$ \\
\hline $\begin{array}{l}\text { Ambient x BINA } \\
\text { Soyaben-2 }\end{array}$ & $0.422 \mathrm{~g}$ & $6.60 \mathrm{de}$ & $96.40 \mathrm{a}$ & $100.40 \mathrm{e}$ & $55.80 \mathrm{c}$ & 2.60 & $13.20 \mathrm{a}$ & $19.16 \mathrm{a}$ \\
\hline Ambient x Shohag & $0.522 \mathrm{~b}$ & $7.25 \mathrm{~b}$ & $72.20 \mathrm{c}$ & $88.40 \mathrm{~g}$ & $41.73 \mathrm{~g}$ & 2.33 & $11.80 \mathrm{e}$ & $11.45 \mathrm{f}$ \\
\hline $\begin{array}{l}\text { Elevated x BINA } \\
\text { Soyaben-1 }\end{array}$ & $0.523 \mathrm{~b}$ & $7.34 \mathrm{~b}$ & $54.31 \mathrm{e}$ & $115.10 \mathrm{a}$ & $55.48 \mathrm{~d}$ & 2.36 & $12.29 \mathrm{~d}$ & $16.09 \mathrm{de}$ \\
\hline $\begin{array}{l}\text { Elevated x BINA } \\
\text { Soyaben-2 }\end{array}$ & $0.444 \mathrm{f}$ & $6.94 \mathrm{c}$ & $65.60 \mathrm{~d}$ & $102.40 \mathrm{~d}$ & $52.38 \mathrm{e}$ & 2.54 & $12.94 \mathrm{bc}$ & $17.21 \mathrm{c}$ \\
\hline Elevated x Shohag & $0.622 \mathrm{a}$ & $9.06 \mathrm{a}$ & $40.60 \mathrm{~g}$ & $98.40 \mathrm{f}$ & $36.05 \mathrm{~h}$ & 2.30 & $10.38 \mathrm{f}$ & $8.61 \mathrm{~h}$ \\
\hline $\begin{array}{l}\text { Cool x BINA Soyaben- } \\
1\end{array}$ & $0.459 \mathrm{e}$ & $6.50 \mathrm{e}$ & $40.40 \mathrm{~g}$ & $105.80 \mathrm{c}$ & $57.90 \mathrm{~b}$ & 2.30 & $12.32 \mathrm{~d}$ & $16.41 \mathrm{~d}$ \\
\hline $\begin{array}{l}\text { Cool x BINA Soyaben- } \\
2\end{array}$ & $0.405 \mathrm{~h}$ & $6.40 \mathrm{e}$ & $48.20 \mathrm{f}$ & $98.40 \mathrm{f}$ & $55.60 \mathrm{~cd}$ & 2.52 & $13.00 \mathrm{~b}$ & $18.22 \mathrm{bc}$ \\
\hline Cool x Shohag & $0.468 \mathrm{~d}$ & $6.50 \mathrm{e}$ & $33.80 \mathrm{~h}$ & $85.30 \mathrm{~h}$ & $42.50 \mathrm{f}$ & 2.16 & $10.30 \mathrm{f}$ & $9.47 \mathrm{~g}$ \\
\hline LSD $(\mathbf{0 . 0 5})$ & 0.993 & 0.370 & 0.763 & 0.756 & 0.375 & 0.165 & 0.198 & 1.067 \\
\hline LS & $* *$ & $* *$ & $* *$ & $* *$ & $* *$ & $\mathrm{NS}$ & $* *$ & $*$ \\
\hline
\end{tabular}

$* *=$ significant at $1 \%$ level of probability

\section{Interaction effect between various types of temperature and varieties on flower abscission percentage at reproductive stage}

The interaction effect of temperatures and varieties on number of flowers plant ${ }^{-1}$, number of pods plant ${ }^{-1}$ and flower abscission percentage are shown in Table 2. Interaction effect between temperature and varieties significantly influenced the abscission percentage of flowers (Table 2). Percentage of flower abscission was found to increase with the increase in temperature in respect of all varieties. It was the highest (63.25, 63.45 and $63.39 \%$ ) in Shohag under elevated temperature treatment at 15-March, 20-March and 25-March, respectively indicating the susceptibility of high temperature. The second highest abscission percentage of flower $(55.56,55.64$ and $55.60 \%)$ was obtained in BINA soybean-2 grown under cool temperature at those stages, respectively. The variety BINA Soybean-2 grown under ambient temperature appeared to have the lowest percentage of flower abscission (44.00, 44.80 and $45.68 \%$ ) at 15-March, 20-March and 25-March, respectively. The results indicated that increasing temperature significantly increase the flower abscission in soybean. Similar study performed by Mann and Jaworski (1970) reported that flowers abscission of soybean cultivars in the polythene house was reduced due to higher temperature where air temperature above $40^{\circ} \mathrm{C}$ caused severe pod abscission.

Table 2. Interaction effect between various types of temperature and varieties on number of flowers and pods plant ${ }^{-1}$, and abscission percentage at reproductive stage

\begin{tabular}{|c|c|c|c|c|c|c|c|c|c|}
\hline \multirow{2}{*}{ Treatments } & \multicolumn{3}{|c|}{ No. of flowers plant ${ }^{-1}$} & \multicolumn{3}{|c|}{ No. of pods plant ${ }^{-1}$} & \multicolumn{3}{|c|}{ Flower abscission (\%) } \\
\hline & 15-Mar & 20-Mar & 25-Mar & 15-Mar & 20-Mar & 25-Mar & 15-Mar & 20-Mar & 25-Mar \\
\hline $\begin{array}{l}\text { Ambient x BINA } \\
\text { Soyaben-1 }\end{array}$ & $110.35 b$ & $110.90 \mathrm{~b}$ & $110.55 b$ & $59.58 \mathrm{a}$ & $59.44 \mathrm{a}$ & $59.47 \mathrm{a}$ & $45.99 \mathrm{~g}$ & $46.40 \mathrm{f}$ & $46.20 \mathrm{e}$ \\
\hline $\begin{array}{l}\text { Ambient x BINA } \\
\text { Soyaben-2 }\end{array}$ & $99.80 \mathrm{e}$ & $101.20 \mathrm{~d}$ & $102.73 d$ & $55.89 \mathrm{c}$ & $55.86 \mathrm{c}$ & $55.70 \mathrm{c}$ & $44.00 \mathrm{~h}$ & $44.80 \mathrm{~g}$ & $45.68 \mathrm{e}$ \\
\hline Ambient x Shohag & $88.00 \mathrm{~g}$ & $88.80 \mathrm{f}$ & $88.40 \mathrm{f}$ & $41.71 \mathrm{f}$ & $41.64 f$ & $41.81 \mathrm{~g}$ & $52.59 \mathrm{c}$ & $53.10 \mathrm{c}$ & $52.69 \mathrm{c}$ \\
\hline $\begin{array}{l}\text { Elevated x BINA } \\
\text { Soyaben-1 }\end{array}$ & $115.10 \mathrm{a}$ & $115.30 \mathrm{a}$ & $114.90 \mathrm{a}$ & $55.82 \mathrm{c}$ & $55.33 \mathrm{c}$ & $55.26 \mathrm{c}$ & $51.50 \mathrm{~d}$ & $52.01 \mathrm{c}$ & $51.90 \mathrm{c}$ \\
\hline $\begin{array}{l}\text { Elevated x BINA } \\
\text { Soyaben- } 2\end{array}$ & $102.10 d$ & $102.60 d$ & $102.50 \mathrm{~d}$ & $52.35 d$ & $52.36 \mathrm{~d}$ & $52.43 d$ & $48.73 \mathrm{f}$ & $48.96 \mathrm{e}$ & $48.85 d$ \\
\hline Elevated x Shohag & 98.10f & $98.70 \mathrm{e}$ & $98.40 \mathrm{e}$ & $36.05 \mathrm{~g}$ & $36.07 \mathrm{~g}$ & $36.03 \mathrm{~h}$ & $63.25 \mathrm{a}$ & $63.45 \mathrm{a}$ & 63.39a \\
\hline Cool x BINA Soyaben-1 & $105.65 \mathrm{c}$ & $105.95 \mathrm{c}$ & $105.80 \mathrm{c}$ & $57.87 \mathrm{~b}$ & $57.93 b$ & $57.90 \mathrm{~b}$ & $45.23 \mathrm{~g}$ & $45.32 \mathrm{fg}$ & $45.27 \mathrm{e}$ \\
\hline Cool x BINA Soyaben-2 & $98.35 \mathrm{f}$ & $98.45 \mathrm{e}$ & $98.40 \mathrm{e}$ & $43.71 \mathrm{e}$ & $43.67 \mathrm{e}$ & $43.68 \mathrm{f}$ & $55.56 \mathrm{~b}$ & $55.64 \mathrm{~b}$ & $55.60 \mathrm{~b}$ \\
\hline Cool x Shohag & $85.15 \mathrm{e}$ & $85.40 \mathrm{~g}$ & $85.36 \mathrm{~g}$ & $42.53 \mathrm{f}$ & $42.48 \mathrm{f}$ & $45.52 \mathrm{f}$ & $50.06 \mathrm{e}$ & $50.25 d$ & $46.67 \mathrm{e}$ \\
\hline $\mathbf{L S D}_{(0.05)}$ & 1.757 & 1.926 & 3.801 & 1.157 & 1.560 & 1.557 & 1.229 & 1.682 & 2.276 \\
\hline LS & $* *$ & $* *$ & $* *$ & $* *$ & $* *$ & $* *$ & $* *$ & $* *$ & $* *$ \\
\hline
\end{tabular}

$* *=$ significant at $1 \%$ level of probability 


\section{Conclusions}

This study clearly indicated that the ambient temperature and the variety BINA soybean-2 singly or their interaction would be the most significant than

\section{References}

Anonymous, 2011. Krishi Diary-2011, Agricultural Information Service, Khamarbari, Farm Gate, Dhaka-1215, 573p.

Ashley, D. A. and Ethridge, W. J. 1978. Irrigation effects on vegetative and reproductive development of three soybean cultivars. Agron. J., 70: 467471.

Davis, J. F. 1945. The effect of some environmental factors on the set of pods and yield of white pea beans. J. Agr. Res., 70: 237-249.

Dornbos, D. L. and Mullen, R. E. 1991. Influence of stress during soybean seed fill on seed weight, germination, and seedling growth rate. J. Plant Science, 71: 373-383.

Eglib, D. B. 2005. Flowering, Pod Set and Reproductive Success in Soya Bean. J. Agronomy and Crop Science, 191(4), 283-291.

Fakir, M. S. A.; Hossain, M. A.; Hossain, A. K. M. Z.; Prodhan, A. K. M A. and S. M., 2000. A study of flower production and abscission in country bean (Lablab purpureus). Bangladesh J. Agric. Sci., 27(2):279-285.

Fisher, V. J. and Weaver, C. K. 1974. Flowering, pod set and pod retention of lima bean in response to night temperature, humidity and soil moisture. $J$. Am. Soc. Hort. Sci., 90: 448-450.

Huxley, P. A.; Summerfied, R. J. and Hughes, P. 1976. Growth and development of soybean CV-TK5 as affected by tropical day lengths, day / night temperatures and nitrogen nutrition. Ann. Apply. Biol., 82:117-133.

Jiwu, Y. and Hong, Y. 1997. The influence of climate change on soybean production in China. J. Agric. Meteorol. Jpn., 52(5): 703-712.

Konsens, I., Ofir, M. and Kigel, J. 1991. The effect of temperature on the production and abscission of flowers and pods in snap bean. Ann. Bot., 67: 391399.

Krote, L. L.; Specth, J. E.; Williams, J. H. and Sorensen, R. C. 1983. Irrigation of soybean genotypes during reproductive ontogeny. Agronomic responses. Crop Sci., 23:521-527.

Lawlor, D. W. 1997. Response of crops to environmenal change conditions: for world food production. J. Agric. Meteorol. Jpn., 52:769-778.

Liu, X. J.; Jian, W. and Herbert, S. J. 2008. Soybean yield physiology and development of high-yielding practices in Northeast China. Field Crops Research, 105: 157-171. other studied temperature stress condition and varieties regarding growth, yield, contributing characters and yield of soybean.

Mann, J. D. and Jaworski, E. G. 1970. Comparison of stresses which may limit soybean yields. Crop Sci., 10: 620-624.

Margesin, and Schinner, F. 1999. Cold adapted organisms ; science; FAO.

Morita, S. 2000. Effects of high air temperature on ripening in rice plants analysis of ripening performance in growth chamber experiments. Jpn. J. Crop. Sci., 69(3):391-399.

Ofier, M.; Gross,Bangerth, F. and Kigel, J. 1993. High temperature effects on pod and seed production as related to hormone levels and abscission of reproductive in common bean (phaseolus vulgaris L.). Sci. Horti., 55(3-4):210-211.

Robins, J. S. And Domingo, C.E. 1953. Some effects of severe soil moisture deficits at specific growth sta -ges in corn. Agron. J., 45:618-62.

Saito, M.; Yamamoto, T.; Goto, K. and Hashimoto, K. 1970. The influence of cool temperatures before and after anthesis on pod setting and nutrients in soybean plants. Proc. Crop Sci. Soc. Jpn., 39:511519.

Shi, C. L.; Jin, Z. Q.; Ge, D. K. and Su, G. L. 2001. Effects of climatie change on crop and adaptation strategies in the middle and lower alleys of the Yangtze river. Jiangsu J. Agril. Sci.,17(7): 1-6. Sionit, N., Strain, B. R. and Flint, E. P. 1987. Interaction of temperature and $\mathrm{CO}_{2}$ enrichment on soybean: Growth and dry matter partitioning. Can. J. Plant Sci., 67: 59-67.

Stobbe, E. H.; Ormrod, D. P. and Woolley, C. J. 1966. Blossoming and fruit set patterns in phaseohus vulgaris L. as influenced by temperature. Can. J. Bot., 44:813-819.

Suppiah, R. 1997. Climate change and its consequences: Model predictions and observation. J. Agric. Meteorol. Jpn., 52(5-9) : 693-702.

Terashima, S.; Masakazu, H. 2001. Characterization and cryoprotective activity of cold responsive dehydrin from Citrus unshiu. Journal of Plant Physiology.158(10):1333-1339

Wang, S. Y. and Zheng, W. 2001. Effect of Plant Growth Temperature on Antioxidant Capacity in Strawberry. Fruit Laboratory, Beltsville Agricultural Research Center, Agricultural Research Service, U.S. Department of Agriculture, Beltsville, Maryland 20705, J. Agric. Food Chem., 49 (10): 4977-4982. 